\title{
Evaluation of yam cultivars for beetle damage \\ FIELD EVALUATION OF EIGHT CULTIVARS OF DIOSCOREA FOR POSSIBLE RESISTANCE TO YAM BEETLE DAMAGE IN OSHIMILI AREA OF DELTA STATE, NIGERIA.
}

\author{
TOBIH, F.O., ERUOTOR, P.G., OKONMAH, L.U AND EGHO, E.O.
}

\author{
Department of Agronomy, Delta State University Asaba Campus, Asaba. Delta State \\ E-mail:tobih002@yahoo.com
}

\begin{abstract}
Trials to evaluate 8 cultivars of yam (Dioscorea species) for possible resistance to yam beetle (Heteroligus sp) damage was conducted at Anwai and Ugbolu in 2004 and 2005 planting seasons in a yam monocrop system. The two sites were located in Oshimili South and North LGA respectively in Delta State. Trials were laid out in a randomized completely block design (RCBD) with three replications. Results showed that all the cultivars tested were susceptible to the yam beetles damage. The two-year results consistently indicated that Dioscorea rotundata were the most susceptible. It was observed that D. alata and D. cayenensis had tuber yields significantly higher (P0.05) than other cultivars. This ranged from 20tha ${ }^{-1}$ and above, irrespective of locations and year of cropping. Least yields were obtained from D. rotundata cv akwukwu-ukpa 7.36, ekpe 11.0, in Anwai in 2004 while 6.50 and 8.26th a $^{-1}$ were recorded at the same location in 2005 respectively for the two cultivars. At Ugbolu location, D. dumetorum and D. cayenensis showed some degree of resistance and tolerance to the beetle with 'mild' damage irrespective of time and location. This may be due partly to the bitter taste and alkaloid properties in D. dumetorum while the late tuber initiation in D. cayenensis may be responsible for the tolerance. Attacked tubers by the beetle were highest in ekpe cultivar which ranged between $77 \%$ to $80 \%$ at both locations and the periods under investigation.
\end{abstract}

KEYWORDS: evaluation, cultivar, resistance yam beetle damage.

\section{INTRODUCTION}

Yam as an important staple food and major source of energy in the diet of most people in the tropics, belongs to the genius Dioscorea and family Diocoreaceae. It is a monocot crop. Important species mostly grown and cultivated in Nigeria are: D. rotundata (white guinea yam), D. alata (water yam or winged yam) and $D$. cayenensis (yellow yam). Species with less economic importance but are cultivated in Nigeria include: $D$. dumetorum, (bitter or trifoliate yam), D. esculenta (Chinese yam) and D. bulbifera (aerial yam). Global yam output was estimated at 32.9 million metric tones in which Nigeria alone produces 23.9 million metric tones equivalent to $71 \%$ of the total world production. (FAOSTAT 1997; FAO, 1998; IITA, 1995). Yam is reputed for the high prices it commands as a result of its socio-cultural values (Chukwu and Chukwu, 2002; Agbaje et al; 2002).

Many factors limit yam production in Nigeria which include high labour demand for most cultural operations; high cost of labour and other inputs such as planting materials; declining soil fertility, pests and diseases (Onwueme, 1978). Yams are attacked by several insects both in the field and during storage. Foliar insect pests are less serious compared to tuber pests. The yam leaf beetles Crioceris Iivida (Dalm) and Lema armata (Fab.) both occur together in yam farm but $C$. Iivida has been reported to be the dominant species in Nigeria (Onwueme, 1978). Mealybug species known to attack yam include Planococcus citri, Planococcus dioscorea, Planococcus halli Ezat McConnel (Akinlosotu, 1984). Other insects that attack yam include yam cricket with species such as Gymnogryllus lucens, Brachytrypes membranaceus, all belong to (Orthoptera:Gryllidae). Other minor field insect pests of yam include leaf miner Laccoptera spp (Cecidomiidae) which induces galls on yam leaves while termite (Isoptera) with species like Amitermes, Macrotermes and Microtermes are widely distributed in West Africa. Yield loss attributed to the attack by

Niger Agric. J. 40 No. 1 (2009): 104 - 110

$-104-$ 
Tobih, F.O., Eruotor, P.G., Okonmah, L.U and Egho, E.O.

termites ranges from zero to $15 \%$ (Wood et al; 1980).

The major and greatest constraint to optimal yam production in yam growing zones such as Delta Niger areas is the damage inflicted on yam tubers by the monophagous dynastid beetles, the Heteroligus species which belongs to the order Coleoptera: Dynastidae (Taylor, 1964; Onwueme, 1978; Tobih et al; 2007). The beetle is highly voracious and losses in field yam tuber as a result of the yam beetle damage has been reported by (Tobih and Emosairue, 2006; Tobih and Emosairue, 2008). To consider using economically feasible and environmentally friendly control measure against any pests, reliable information is essential on yield losses due to the pest attack and the control method being adopted (Kumar, 1984).

The incidence, distribution, damage potentials and most importantly, the management of yam tuber beetles is of current concern throughout the yam growing belts in Nigeria and the continent of Africa where yam is grown. Nonetheless, studies on resistance of yam varieties to infestation by yam beetles are limited and scanty. This study was undertaken therefore, to evaluate the response and performance of eight cultivars of yam varieties to yam beetle damage and the yield response to the beetle attack.

\section{MATERIALS AND METHODS}

The studies were conducted at two locations; one at Teaching and Research Farms of Faculty of Agriculture Anwai, Delta State University Asaba Campus and Ugbolu, a Village in Oshimili North Local Government area of Delta State in 2004 and 2005 planting seasons. Plots of land which has been left fallow for at least 5 years were chosen for both locations. The farmland were manually cleared and properly rouged of any debris and root stumps. Thereafter, an area of $47 \mathrm{~m} \times 11 \mathrm{~m}\left(517 \mathrm{~m}^{2}\right)$ was mapped out into $5 \mathrm{~m} \mathrm{x} 3 \mathrm{~m}$ plots and made into mounds manually with Abakaliki traditional hoe (Ikeorgu and Igwilo, 2002). Mixed tuber yam setts sized $250-300 \mathrm{~g}$ were planted per mound at $1 \mathrm{~m} \times 1 \mathrm{~m}$ with $1 \mathrm{~m}$ border lines fitted into a randomized completely block design (RCBD). This consisted of 8 treatments (yam cultivars) and replicated three times. A replicate consisted of 15 heaps/mounds (15 yam stands)/replicate. Planted yam setts in 2004 were purchased from Ugbolu yam market while tubers harvested were used for 2005 re-planting. Treatments consisted of the under listed eight yam cultivars.

Table 1. Names of yam cultivars evaluated for possible field resistance to infestation by the yam beetles.

\begin{tabular}{lll}
\hline Species & $\begin{array}{l}\text { Cultivated Variety }(\mathrm{CV}) \\
\text { Local varieties }\end{array}$ & Common name \\
\hline Dioscorea rotundata (Poir) & Adaka & White guinea yam \\
D. rotundata (Poir) & Obioturugo & White guinea yam \\
D. rotundata (Poir) & Abi & White guinea yam \\
D. rotundata (Poir) & Akwukwutukpa & White guinea yam \\
D. rotundata (Poir) & Ekpe & White guinea yam \\
D. alata $($ L) & Sudanese & Water or winged yam \\
D. dumetorum $($ Kunth) Pax & Ona & Bitter or trifoliate yam \\
D. cayenensis $($ Lam $)$ & Oku & Yellow yam \\
\hline
\end{tabular}

Planting was done from the $20^{\text {th }}-21^{\text {st }}$ May 2004 and harvested from the $10-12^{\text {th }}$ December same year for both locations while 2005 planting was done from $17^{\text {th }}-18^{\text {th }}$ May and harvested from $8^{\text {th }}-9^{\text {th }}$ December. The yams were grown under rain-fed condition and were under natural soil fertility condition without fertilizer application. Fields were kept weeds free by regular manual weeding throughout the duration of the study.

Tuber weight, the freshly harvested tubers were weighed using top loading scale balance and each tuber weight recorded accordingly. For feeding holes; the harvested tubers were physically examined for yam beetle feeding and identified holes were counted with the aid of black marker. Depth and diameter of the 


\section{Evaluation of yam cultivars for beetle damage}

beetle feeding holes were carefully measured using a white thread to trace depth of the hole and the width. This was later traced on a ruler to determine the actual depth and diameter of the feeding holes. Percentage tuber attacked by the beetle was calculated by subtracting all tubers with beetle feeding holes from the total number of tubers harvested. This was further divided by the total number of tubers harvested per treatment and multiplied by 100. Severity of infestation/damage was based on Agbaje et al (2002) rating with some modification. Where:

1. $=$ no beetle feeding hole on the yam tuber.

2. $=$ mild (1-3 beetle feeding holes on the tuber).

3. $=$ moderate infestation ( $4-8$ beetle feeding holes on the tuber).

4. $\quad=$ Severe infestation (9-15) beetle feeding holes on the tuber.

5. $=$ Very severe infestation $(\geq 15)$ beetle feeding holes on the tuber.

Data collected at harvest included: Weight of freshly harvested yam tuber, number of beetle feeding hole/tuber; percentage of harvested tubers damaged by the beetle, severity of beetle infestation, diameter and depth of beetle feeding holes. Data were subjected to analysis of variance (ANOVA) and significant means were separated by Duncan New Multiple Range Test (DNMRT) at 5\% level of significance.

\section{RESULTS}

The results of the evaluation of eight cultivars of Dioscorea spp for possible resistance to yam beetle damage at Anwai in 2004 and 2005 cropping seasons are shown on (Tables 2 and 3). The results obtained showed that $D$. alata and $D$. cayenensis had significantly higher (P0.05) tuber yields than other cultivars evaluated. The lowest yield in 2004 were recorded from akwukwu-ukpa $\left(7.36 \mathrm{t} / \mathrm{ha}^{-1}\right)$ and ekpe $\left(11.01 \mathrm{t} / \mathrm{ha}^{-1}\right)$, both belong to rotundata (white yam) with their yields significantly $(\mathrm{P} \leq 0.05)$ lower than other cultivars. Percentage tuber infested by the beetles indicated that ekpe was more prone to infestation (77\%), closely followed by adaka (72\%), Obioturugo (70\%) and water yam (71\%). They were, however, not significantly different (P0.05) from each other and obioturugo (70.33). The most damaged cultivar was ekpe with severity score of (4.66) and it was significantly $(\mathrm{P} \leq 0.05)$ higher than severity scores in other cultivars. Damage indices such as depth, diameter and number of beetle feeding holes indicated yellow yam and (trifoliate) bitter yam to be less damaged while ekpe and obioturugo were most damaged. The tuber yield followed the same trend in 2005 as was in 2004 and ranged between $19.33 \mathrm{t} / \mathrm{ha}^{-1}$ in abi and $30.46+/ \mathrm{ha}^{-1}$ in water yam, while the least yields of $6.5+/ \mathrm{ha}^{-1}$ and $8.26 \mathrm{t} / \mathrm{ha}^{-1}$ were obtained in akwukwu-ukpa and ekpe cultivars respectively. Similarly, ekpe plots had the highest incidence of beetle attack $(78 \%)$ which was significantly higher $(\mathrm{P} \leq 0.05)$ than other cultivars, while the damage severity in the same cultivar (ekpe) indicates 'severe' damage. The least number of beetle feeding holes were recorded in both yellow and trifoliate/bitter yam and were significantly lower $(\mathrm{P} \leq 0.05)$ than those in $a b i$, adaka, ekpe and obioturugo plots. 
Tobih, F.O., Eruotor, P.G., Okonmah, L.U and Egho, E.O.

Table 2: Evaluation of eight cultivars of Dioscorea for possible resistance to Yam damage at Anwai in 2004 planting season

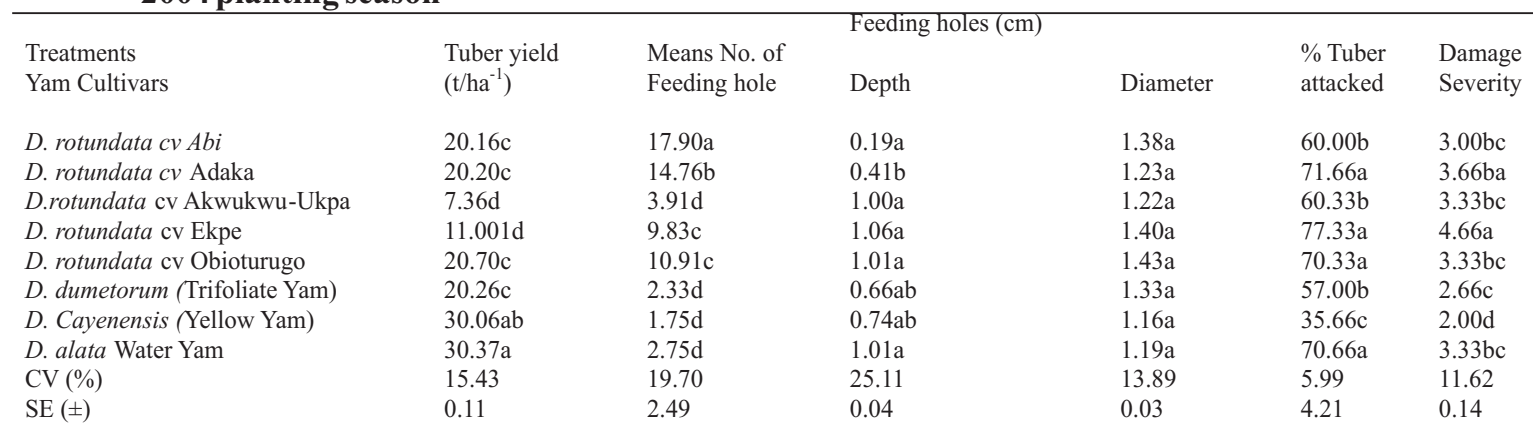

Means followed by the same letter are not significantly different at $5 \%$ level according to Duncan New multiple Range Test (DNMRT)

Table 3: Evaluation of eight cultivars of Dioscorea for possible resistance to Yam damage at Anwai in 2005 planting season

\begin{tabular}{|c|c|c|c|c|c|c|}
\hline & & & Feeding & & & \\
\hline $\begin{array}{l}\text { Treatments } \\
\text { Yam Cultivars }\end{array}$ & $\begin{array}{l}\text { Tuber yield } \\
\left(\mathrm{t} / \mathrm{ha}^{-1}\right)\end{array}$ & $\begin{array}{l}\text { Means No. of } \\
\text { Feeding hole }\end{array}$ & Depth & Diameter & $\begin{array}{l}\% \text { Tuber } \\
\text { attacked }\end{array}$ & $\begin{array}{l}\text { Damage } \\
\text { Severity }\end{array}$ \\
\hline D. rotundata cv Abi & $19.33 b$ & $16.00 \mathrm{a}$ & $0.95 \mathrm{ab}$ & $1.13 \mathrm{a}$ & $57.66 \mathrm{~b}$ & $3.00 \mathrm{bc}$ \\
\hline D. rotundata cv Adaka & $20.00 \mathrm{~b}$ & $13.33 \mathrm{a}$ & $0.75 \mathrm{ab}$ & $1.30 \mathrm{a}$ & $64.66 \mathrm{~b}$ & $3.33 \mathrm{~b}$ \\
\hline D.rotundata cv Akwukwu-Ukpa & $6.50 \mathrm{c}$ & $3.50 \mathrm{~b}$ & $0.94 a b$ & $1.23 \mathrm{a}$ & $64.33 b$ & $3.33 b$ \\
\hline D. rotundata $\mathrm{cv}$ Ekpe & $8.26 \mathrm{c}$ & $10.33 \mathrm{a}$ & $1.06 \mathrm{a}$ & $1.30 \mathrm{a}$ & $77.66 \mathrm{a}$ & $4.33 \mathrm{a}$ \\
\hline D. rotundata cv Obioturugo & $20.43 \mathrm{ab}$ & $12.00 \mathrm{a}$ & $1.02 \mathrm{ab}$ & $1.06 \mathrm{a}$ & $58.33 b$ & $2.66 \mathrm{bc}$ \\
\hline D. dumetorum (Trifoliate Yam) & $20.16 b$ & $2.16 \mathrm{a}$ & $0.66 \mathrm{~b}$ & $1.09 \mathrm{a}$ & $46.00 \mathrm{c}$ & $2.33 c$ \\
\hline D. Cayenensis (Yellow Yam) & $20.61 \mathrm{ab}$ & $1.43 b$ & $0.78 \mathrm{ab}$ & $1.21 \mathrm{a}$ & $40.66 \mathrm{c}$ & $2.33 \mathrm{c}$ \\
\hline D. alata Water Yam & $30.46 \mathrm{a}$ & $4.00 \mathrm{~b}$ & $0.99 \mathrm{ab}$ & $1.46 \mathrm{a}$ & $62.00 \mathrm{~b}$ & 16.40 \\
\hline $\mathrm{CV}(\%)$ & 28.08 & 42.59 & 21.53 & 19.71 & 10.34 & 16.40 \\
\hline $\mathrm{SE}( \pm)$ & 0.31 & 11.17 & 0.03 & 0.05 & 37.17 & 0.25 \\
\hline
\end{tabular}

Means followed by the same letter are not significantly different at $5 \%$ level according to Duncan New multiple Range Test (DNMRT)

The analysis of variance indicated highly significant $(\mathrm{P} \leq 0.05)$ differences between the white yam and yellow yam at Ugbolu location in 2004. The highest $\%$ of tuber infestation by the beetle was recorded in ekpe cultivar (79\%) which was significantly higher than \% infestation in infestation in other cultivars, suggestive that the cultivar is more prone to the beetle damage (Table 4). Trifoliate and yellow yams had $40 \%$ and 35\% infestation respectively which suggests reduced proness to the beetle infestation. These severity scores for trifoliate and yellow yam plots suggest their ability to withstand beetle damage compared to cultivars like ekpe, adaka (white yams). The results obtained in 2005 cropping at Ugbolu are shown on Table 5. Cultivars with yields of 20/tons per hectare and above included abi, (20.16) obioturugo, (20.25) yellow 20.58 and water yams (20). These yields were significantly $(\mathrm{P} \leq 0.05)$ higher than yields from akwukwu-ukpa, (7.20) ekpe (6.63) and trifoliate yams (11.63). The highest \% of tuber infestation of $80 \%$ and $70 \%$ were found in ekpe and water yam plots respectively and the same trend was observed in 2004 planting season. However, yellow and trifoliate yams showed significantly lower level of tuber infestation of $31 \%$ and $42 \%$ respectively. The two-year study at both locations indicated that white yams are generally more susceptible to the beetle damage than yellow and trifoliate/bitter yams. 
Evaluation of yam cultivars for beetle damage

\section{Table 4: Evaluation of eight cultivars of Dioscorea for possible resistance to Yam damage at Ugbolu in 2004 planting season}

\begin{tabular}{|c|c|c|c|c|c|c|}
\hline & & & $\begin{array}{l}\text { Feeding } \\
\text { holes }(\mathrm{cm})\end{array}$ & & & \\
\hline $\begin{array}{l}\text { Treatments } \\
\text { Yam Cultivars }\end{array}$ & $\begin{array}{l}\text { Tuber } \\
\text { yield } \\
\left(\mathrm{t} / \mathrm{ha}^{-1}\right)\end{array}$ & $\begin{array}{l}\text { Means No. } \\
\text { of } \\
\text { Feeding } \\
\text { hole }\end{array}$ & Depth & Diameter & $\begin{array}{l}\% \text { Tuber } \\
\text { attacked }\end{array}$ & $\begin{array}{l}\text { Damage } \\
\text { Severity }\end{array}$ \\
\hline D. rotundata $c v A b i$ & $18.26 \mathrm{c}$ & $21.83 \mathrm{a}$ & $1.23 \mathrm{ab}$ & $1.13 \mathrm{a}$ & $56.00 \mathrm{c}$ & $3.33 \mathrm{c}$ \\
\hline $\begin{array}{l}\text { D. rotundata } \mathrm{cv} \\
\text { Adaka }\end{array}$ & $15.03 \mathrm{dc}$ & $13.58 b$ & $1.21 \mathrm{ab}$ & $1.26 \mathrm{a}$ & $57.66 \mathrm{~b}$ & $4.00 \mathrm{ab}$ \\
\hline $\begin{array}{l}\text { D.rotundata cv } \\
\text { Akwukwu-Ukpa }\end{array}$ & $7.20 \mathrm{e}$ & $3.00 \mathrm{~d}$ & $1.13 \mathrm{ab}$ & $1.05 \mathrm{a}$ & $65.33 b$ & $3.33 \mathrm{c}$ \\
\hline D. rotundata cv Ekpe & $6.63 \mathrm{e}$ & $9.33 \mathrm{bc}$ & $1.33 \mathrm{ab}$ & $1.16 \mathrm{a}$ & $78.66 \mathrm{a}$ & $4.33 \mathrm{a}$ \\
\hline $\begin{array}{l}\text { D. rotundata } \mathrm{cv} \\
\text { Obioturugo }\end{array}$ & $20.26 a$ & $12.41 \mathrm{~b}$ & $1.16 \mathrm{ab}$ & $1.36 \mathrm{a}$ & $62.66 \mathrm{c}$ & $3.33 \mathrm{c}$ \\
\hline $\begin{array}{l}\text { D. dumetorum } \\
\text { (Trifoliate Yam) }\end{array}$ & $11.26 \mathrm{de}$ & $2.33 \mathrm{~d}$ & $0.81 \mathrm{ab}$ & $0.95 \mathrm{a}$ & $40.00 \mathrm{~d}$ & $2.33 \mathrm{~d}$ \\
\hline $\begin{array}{l}\text { D. Cayenensis } \\
\text { (Yellow Yam) }\end{array}$ & $20.86 a$ & $2.00 \mathrm{~d}$ & $0.73 b$ & $0.95 \mathrm{a}$ & $35.00 \mathrm{~d}$ & $2.00 \mathrm{~d}$ \\
\hline D. alata Water Yam & $20.18 \mathrm{ab}$ & $7.25 \mathrm{~cd}$ & $1.40 \mathrm{a}$ & $1.10 \mathrm{a}$ & $65.33 b$ & $3.66 \mathrm{bc}$ \\
\hline CV $(\%)$ & 22.03 & 31.36 & 27.25 & 23.16 & 7.32 & 9.66 \\
\hline $\mathrm{SE}( \pm)$ & 0.03 & 7.91 & 0.09 & 0.06 & 18.58 & 0.1 \\
\hline
\end{tabular}

Means followed by the same letter are not significantly different at 5\% level according to Duncan New multiple Range Test (DNMRT)

Table 5: Evaluation of eight cultivars of Dioscorea for possible resistance to Yam damage at Ugbolu in 2005 planting season

\begin{tabular}{|c|c|c|c|c|c|c|}
\hline & & & Feeding & & & \\
\hline $\begin{array}{l}\text { Treatments } \\
\text { Yam Cultivars }\end{array}$ & $\begin{array}{l}\text { Tuber yield } \\
\left(\mathrm{t} / \mathrm{ha}^{-1}\right)\end{array}$ & $\begin{array}{l}\text { Means No. of } \\
\text { Feeding hole }\end{array}$ & Depth & Diameter & $\begin{array}{l}\% \text { Tuber } \\
\text { attacked }\end{array}$ & $\begin{array}{l}\text { Damage } \\
\text { Severity }\end{array}$ \\
\hline D. rotundata $c v A b i$ & $20.16 \mathrm{a}$ & $17.33 \mathrm{a}$ & $1.25 \mathrm{a}$ & $1.17 \mathrm{~b}$ & $53.33 \mathrm{~cd}$ & $3.00 \mathrm{~cd}$ \\
\hline D. rotundata $c v$ Adaka & $15.00 \mathrm{bc}$ & $13.66 \mathrm{ab}$ & $1.32 \mathrm{a}$ & $1.23 b$ & $64.00 \mathrm{bc}$ & $3.33 \mathrm{bc}$ \\
\hline D.rotundata cv Akwukwu-Ukpa & $10.43 \mathrm{c}$ & $8.66 \mathrm{c}$ & $1.13 \mathrm{ab}$ & $1.36 \mathrm{ab}$ & $62.33 \mathrm{bc}$ & $3.33 \mathrm{bc}$ \\
\hline D. rotundata $\mathrm{cv}$ Ekpe & 9.26 & $9.50 \mathrm{bc}$ & $1.28 \mathrm{a}$ & $1.20 \mathrm{~b}$ & $80.00 \mathrm{a}$ & $4.66 \mathrm{a}$ \\
\hline D. rotundata cv Obioturugo & $20.25 \mathrm{ab}$ & $13.00 \mathrm{ab}$ & $1.32 \mathrm{a}$ & $1.31 \mathrm{ab}$ & $60.00 \mathrm{bc}$ & $3.33 \mathrm{bc}$ \\
\hline D. dumetorum (Trifoliate Yam) & $9.66 \mathrm{c}$ & $3.33 \mathrm{~cd}$ & $0.98 \mathrm{ab}$ & $1.21 \mathrm{~b}$ & $42.00 \mathrm{de}$ & $2.33 \mathrm{de}$ \\
\hline D. Cayenensis (Yellow Yam) & $20.58 \mathrm{a}$ & $2.00 \mathrm{~d}$ & $0.81 \mathrm{~b}$ & $0.88 \mathrm{c}$ & $31.33 \mathrm{e}$ & $2.00 \mathrm{e}$ \\
\hline D. alata Water Yam & $20.00 \mathrm{ab}$ & $10.33 b$ & $1.13 \mathrm{ab}$ & $1.50 \mathrm{a}$ & $70.00 \mathrm{ab}$ & $4.00 \mathrm{ab}$ \\
\hline CV $(\%)$ & 28.32 & 36.23 & 16.26 & 10.89 & 13.43 & 15.56 \\
\hline $\mathrm{SE}( \pm)$ & 0.21 & 12.42 & 0.04 & 0.01 & 60.75 & 0.25 \\
\hline
\end{tabular}

Means followed by the same letter are not significantly different at 5\% level according to Duncan New Multiple Range Test (DNMRT) 
Tobih, F.O., Eruotor, P.G., Okonmah, L.U and Egho, E.O.

\section{DISCUSSION}

From the eight cultivars of Dioscorea evaluated, only two cultivars: D. dumetorum and D. cayenensis consistently show some degrees of resistance to yam beetle damage. Damage severity score was also low for the two cultivars irrespective of locations and year of cropping. D. rotundata (cvs) ekpe, adaka and akwukwu$u k p a$ were the most damaged and appear more proned to the beetle attack. Yields of D. rotundata (cvs) abi, adaka and obioturugo were relatively high despite the high beetle feeding indices and other damage related parameters on the tubers. These may be due to their ability to recuperate from damage done by the beetle. This is similar to the report of Kumar (1984) which suggested that resistant yam cultivars are able to produce meaningful yield inspite of serious beetles attack and damage.

On the contrary, $D$. dumetorum and $D$. cayenensis had tuber yield usually above 20 tons per hectare with less beetle damage which may perhaps be attributed to the high yields recorded in these cultivars across the locations and year of cropping. According to Degras (1993) disparities observed in the infestation level and the severity between yam and cultivars could partly be attributed to their biochemical composition. D. rotundata is sweeter to taste unlike $D$. dumetorum with bitter taste which may be the reason why the former is widely cultivated in Nigeria than the latter. However, the tolerance/resistance observed in $D$. cayenensis may be attributable to its late tuber initiation and formation (tuberization) which in most cases do not coincide with the peak destructive periods of the beetle population density. It has been reported that of all known food yam species in Nigeria, only D. esculenta (Chinese yam), is fully resistant or immune to yam beetle damage. All other species have varied degrees of damage by the monophagous yam beetle (Heteroligus spp) (Emehute, et al; 1998). Plant resistance is important in pest management and a high degree of resistance/tolerance is particularly desirable for yam beetle management. Resistance according to Painter (1951) and Hamson et al (1979), in general terms describes the relative response of a crop to attack by insect pests, disease pathogens or any other pest organisms. These insects are classified on the basis of three possible mechanisms:

(i) Antibiosis resistance is the ability of a host to injure the pest, reduce reproduction potential, retard rate of development or kill the pest outrightly.

(ii) Non-preference refers to the plants characters and insect response that lead an insect away from a plant or plant part for oviposition, food, shelters or the combination of the three (Painter, 1951).

(iii) Tolerance refers to the capacity and ability of the plant to grow and reproduce, itself or to repair injury to a marked degree in spite of supporting a population density of insects approximately equal to that damaging a susceptible variety or cultivar (Painter, 1951).

Ashomo, (2004) evaluated the nutrients available for yam moth Dasyses rugosella Stainton (Lepidoptera:Tineidae) and reported that D. alata was most suitable for the development and survival of larval stages. Accordingly, percentage adult emergence was highest (53.3\%) while development periods was shortest (62.4 days). On the contrary, $20 \%$ adult emergence and development period of 70.7 days was reported in $D$. dumetorum. These findings further give credence to the tolerance of D.dumetorum to insect pests particularly yam beetle relative to other cultivars evaluated. Results from another trial conducted on some new yam hybrid (Dioscorea rotundata Poir) varieties at Ibadan indicated 'mild' infestation (resistant/tolerant) to yam beetle, nematode and Planococcus halli (mealybug) on tubers but varietal differences were not observed (Agbaje et al, 2002).

The results from this study show the possibility of breeding yam variety/cultivar that could be highly resistant to yam beetle damage especially varieties like $D$. dumetorum, $D$. cayenensis and other promising varieties that show some tolerance/resistance traits to beetle damage.

Availability of yam cultivars that are less prone to infestation and damage by the yam beetles will enhance tuber yields and promote better quality for increased returns to farmers and optimum quality to consumers. 
Evaluation of yam cultivars for beetle damage

\section{REFERENCES}

Agbaje, G.O., Adegbite, A.A., Akinlosotu, T.A. and Soyinka S.A. (2002). Performance of new hybrid yam (Dioscorea rotundata Poir) varieties under different cropping system. African Journal of Root and Tuber Crops 5:1:8-11.

Akinlosotu, T.A. (1984). Planococcus halli, a new mealy bug pest of white yam (D. rotundata) at Moor plantation, Ibadan, Nigeria. India Journal of Root Crops 10(1 \&2):71-73.

Ashomo, M.O. (2004). Development of the yam moth Dayses rugosella stainon (Lepidoptera:Tineidae) in different yam varieties. In: Book of Abstract $35^{\text {th }}$ Annual Conference of Entomological Society of Nigeria held at Akure October $3^{\text {rd }}-7^{\text {th }}, 2004$.

Chukwu, G.O. and Chukwu, K.E. (2002). Cosmovision and Folk science in yam production. Proceeding $36^{\text {th }}$ Annual Conference of Agricultural Society of Nigeria. Federal University of Technology, Owerri. Pp 125-129.

Degras, L.M. (1993). The yam. A Tropical Root Crop. Macmillan Press Ltd., London and Basingstoke 408pp.

Emehute, J.K.U, Ikotun T., Nwauzor, E.C. and Nwokocha, H.N. (1998). Crop protection. In: Food yams; Advances in Research. Orkwor C.C. Asiedu, R and I.J. Ekanayake eds. Pp 141-186

FAO (1998). Food and Agriculture Organization Production Year Book, FAO Rome, Italy.

FAO STAT (1997) CDROM

Hamson, C.H., Schafer, J.F and Turnipseed, S.G. (1979). Genetic Resistance for crop Protection. In: Introduction to crop protection ed. W.B. Ennis Jr. American Society of Agronomy-Crop Science Society of America, Madison, Wisconsin. Pp. 102-129.

IITA (1995). Institute of Tropical Agriculture yam Research at IITA:1971-1993. Crop Improvement Division, Root and Tuber Improvement Program IITA Ibadan Nigeria. 38pp.

Ikeorgu, J.E.G and Igwilo, H.N. (2002) Effect of mulching and staking on yam growth under irrigation during the dry season in Umudike, South Eastern Nigeria. Journal of Sustainable Agric and Envirom. $4(1): 129-132$

Kumar, R (1984). Insect control with special reference to African Agriculture. Edward Arnold Pub. Ltd., London, 298pp.

Onwueme, I.C. (1978). The tropical Root and Tubers Crops: Yams, Cassava, Sweet Potato and Cocoyams. John Wiley and Sons. New York. 234pp.

Painter, R.H. (1951). Insect resistance in crop plants. Macmillan, New York. 520pp.

Taylor, T.A (1964). Studies on the Nigerian Yam Beetles. II: Bionomics and control. Journal of West African Science Assoc. 9(1):13-31.

Tobih, F.O. and Emosairue, S.O. (2006). Assessment of yam beetle damage under a screen house condition. The Nigerian Agricultural Journal. 37:50-52.

Tobih, F.O. Emosairue, S.O. and Okonmah L.U. (2007) Studies on the occurrence and damage by yam tuber beetles (Heteroligus spp) in Aniocha and Oshimili Areas of Delta State, Nigeria. Journal of Central European Agriculture 8(1):129-134.

Tobih, F.O. and Emosairue, S.O. (2008). Damage by yam beetle, Heteroligus meles (Coloeptera: Dynastidae) under different population in yam cropping system. Global Journal of Pure and Applied Sciences 14 (1) $5-8$.

Wood, T.G. Smith R.W. Johnson, F.A. and Komolafe, P.O. (1980). Termite damage and crop loss studies in Nigeria-preharvest losses to yam due to termite and other soil pests. Tropical pest management. 26(4):355-370.

Niger Agric. J. 40 No. 1 (2009): 104 - 110

$-110-$ 